\title{
Immune defects and cardiovascular risk in $X$ chromosome monosomy mosaicism mediated by loss of chromosome $Y$. A risk factor for SARS- CoV-2 vulnerability in elderly men?
}

\author{
Luis A. Pérez-Jurado ${ }^{1,2, \star}$, Alejandro Cáceres ${ }^{3}$, Tonu Esko ${ }^{4}$, Juan R. González ${ }^{3,5, *}$
}

1. Genetics Unit, Universitat Pompeu Fabra, Hospital del Mar Research Institute (IMIM), and Centro de Investigación Biomédica en Red de Enfermedades Raras (CIBERER), Barcelona, Spain.

2. SA Clinical Genetics, Women's and Children's Hospital, South Australian Health and Medical Research Institute and The University of Adelaide, Adelaide, Australia.

3. Barcelona Institute for Global Health (ISGlobal), and Centro de Investigación Biomédica en Red en

Epidemiología y Salud Pública (CIBERESP), Barcelona, Spain.

4. Estonian Genome Centre Science Centre, University of Tartu, Tartu, Estonia.

5. Dept. of Mathematics, Universitat Autònoma de Barcelona, Bellaterra (Barcelona), Spain.

*To whom correspondence should be addressed - email: luis.perez@upf.edu /

juanr.gonzalez@isglobal.org.

\section{Abstract}

The ongoing pandemic caused by severe acute respiratory syndrome coronavirus 2 (SARSCoV-2, COVID-19) has an estimated overall case fatality ratio of $1.38 \%$ in China, being $53 \%$ higher in males and increasing exponentially with age. Mosaicism for $\mathrm{X}$ chromosome monosomy $(\mathrm{XCM})$ shows a similar increase in aging population mostly driven by loss of chromosome $\mathrm{Y}$ in males (LOY), and is associated with a raise in all-cause mortality. Using comparative transcriptomic data, we have defined that XCM/LOY is associated with abnormal peripheral blood cell counts with decreased progenitor cells and multiple biomarkers of immune system dysfunction, pro-coagulation activity and increased cardiovascular risk. Several differentially down-regulated genes in XCM/LOY individuals are involved in the initial immune response to SARS-CoV-2 (OR of enrichment=7.23, $\mathrm{p}=1.5 \times 10^{-7}$ ), mainly interferon-induced genes that code for inhibitors of viral processes. Thus, our data suggest that XCM mosaicism underlies at least part of the sex-biased severity and mortality of COVID-19 in aging patients. Given its potential relevance for modulating prognosis and therapeutic response, we propose that evaluation of LOY and XCM by currently established methods should be implemented as biomarkers in infected patients, including currently ongoing clinical trials with different medications and vaccines for COVID-19. Testing for LOY/XCM at large scale among elderly people may also be helpful to identify still unexposed people who may be especially vulnerable to severe Covid-19 disease.

\section{Introduction}

The ongoing pandemic of coronavirus disease 2019 (COVID-19) caused by severe acute respiratory syndrome coronavirus 2 (SARS-CoV-2) represents a major health threat to the entire world. ${ }^{1}$ As of April 19, 2020, there have been more than 2.3 million confirmed cases of COVID19 worldwide, with more than 160,000 deaths reported. While good estimates of the case fatality ratios are widely lacking, it is clear that mortality is highest in old men. A best reported 
medRxiv preprint doi: https://doi.org/10.1101/2020.04.19.20071357; this version posted April 24, 2020. The copyright holder for this preprint (which was not certified by peer review) is the author/funder, who has granted medRxiv a license to display the preprint in perpetuity. It is made available under a CC-BY-NC-ND 4.0 International license .

estimate of the overall case fatality ratio after adjusting for demography and underascertainment in the initial outbreak in China was $1.38 \%$ (95\% Cl 1.23-1.53), being significantly higher with aging (6.4\% in $\geq 60$ and $13.4 \%$ in $\geq 80$ age groups) and in males; $2.8 \%$ as compared with $1.7 \%$ in females ${ }^{2}$. Emergent data of the age-stratified case fatality ratio and infection fatality ratio in other countries show a similar pattern with a remarkable sex-bias increasing with advancing age. The numbers and proportions may even further increase when patients in aged care facilities are fully registered. Sex-dependent differences in disease outcomes were also found during the past SARS-CoV and MERS-CoV epidemics ${ }^{3,4}$ and in mice infected with the virus. ${ }^{5}$

Understanding the underlying basis of this different sex and age vulnerability is crucial because men and women are likely to have fundamentally different reactions to the SARS-CoV-2 virus infection, possible treatments and vaccines. Proposed causes include different case definition of disease, different environmental factors (such as life-style, smoking history or workenvironment) and sex-specific immune-defense factors. In particular, the $\mathrm{X}$ chromosome harbors multiple genes important for immunity and there are many $\mathrm{X}$-linked immunodeficiencies, so males have greater susceptibility to infections starting at birth. ${ }^{6}$ More specifically, SARS viruses use the angiotensin converting enzyme (ACE2), encoded by an X-linked gene, as a receptor to enter and infect ACE-2 expressing cells. ${ }^{1}$ Thus, sex variation in the expression of this gene with paradoxically higher expression and higher circulating levels in men than in women has also been proposed as a candidate mechanism. ${ }^{7}$ However, ascertainment bias and environmental factors are unlikely to prevail in different populations while the gender-specific immune factors or ACE2 variation would not fully explain the increased risk and sex-divergence with aging.

Developmental (causing Turner syndrome) or late onset $X$ chromosome monosomy in mosaicism (XCM), usually with loss of the inactive X-chromosome, is detectable in female leukocytes with a frequency that increases with age $(0.05 \%$ in 50 -year olds; $0.25 \%$ in 75 -year olds). ${ }^{8}$ Individuals with XCM have an increased risk for autoimmune disease, recurrent viral infections and earlier cardiovascular mortality, ${ }^{9}$ which has been attributed to X-chromosome haploinsufficiency for multiple genes, and is associated with excessive production of proinflammatory cytokines (IL-6), decrease in anti-inflammatory cytokines (IL-10, TGF- $\beta$ ) and a lower CD4:CD8 ratio. ${ }^{10}$ In men, mosaic XCM is much more common, acquired by somatic loss of the $\mathrm{Y}$ chromosome (LOY). LOY is an age related phenomenon that has been associated with a wide spectrum of human diseases including cancer, Alzheimer's disease, cardiovascular disease, and reduced overall life expectancy in men. ${ }^{11-14}$ Genetic variation in multiple loci is involved in the inherited susceptibility to LOY, which can also be driven by smoking and other environmental exposures. ${ }^{15}$ LOY is the most common copy number alteration in male leukocytes, estimated to occur in $<2 \%$ men under 60 years of age, but exponentially increasing with aging to $15-40 \%$ in $70-85$ year-old males and $>50 \%$ at 93 years of age.$^{15}$ Extreme down- 
medRxiv preprint doi: https://doi.org/10.1101/2020.04.19.20071357; this version posted April 24, 2020. The copyright holder for this preprint (which was not certified by peer review) is the author/funder, who has granted medRxiv a license to display the preprint in perpetuity.

It is made available under a CC-BY-NC-ND 4.0 International license .

regulation of chromosome $\mathrm{Y}$ gene expression mainly driven by genes with $\mathrm{X}$-chromosome homologs that escape $\mathrm{X}$-inactivation seems to be the functional mediator of the reported association between LOY and disease. ${ }^{16,17}$

We, therefore, advance the hypothesis that XCM/LOY is an underlying factor for the increased severity and mortality of COVID-19 in aging men. While data is yet unavailable to directly test this hypothesis, we have gathered convincing and consistent evidence from current sources of information.

We have correlated XCM due to LOY in aging males with multiple parameters of cardiovascular dysfunction, and defined the transcriptomic deregulation that underlies disease risks, including signatures of immune system dysfunction and increased coagulation activity. We have finally studied how some of the genes deregulated by LOY are involved in the response to SARSCoV-2 infection.

\section{Methods}

Covid-19infection, mortality data and LOY prevalence estimates

Accumulated data until 6th April, 2020 was obtained from the Spanish ((https://www.isciii.es/QueHacemos/Servicios/VigilanciaSaludPublicaRENAVE/EnfermedadesTr ansmisibles/Paginas/InformesCOVID-19.aspx) Italian (https://www.epicentro.iss.it/coronavirus/) National Epidemiological registries. Mortality stratified by sex for different countries was obtained from ISCIII reports. Data on the age-stratified number of infected cases and mortality in 7 age groups (<30, 30-39, 40-49, 50-59, 60-69, 70-79, $80+$ ) in Italy and Spain was used to estimate difference in lethality between males and females. LOY prevalence estimates by age were obtained from general population belonging to UK Biobank. ${ }^{14}$

\section{Subjects, genotype and phenotype data}

LOY was assessed in a total of 530 adult men belonging to the Estonian Gene Expression Cohort (EGCUT, www.biobank.ee) that comprises a large cohort of 53,000 samples of the Estonian Genome Center Biobank, University of Tartu. Detailed phenotypic information from all the individuals studied, including clinical analysis (blood cell counts and general biochemistry) and follow-up until June 2020, was available in ICD-10 codes. Patients selected in this study were genotyped using OmniX array. All individuals had genotyping success rate above $95 \%$. All studies were performed in accordance with the ethical standards of the responsible committee on human experimentation, and with proper informed consent from all individuals tested.

\section{Bulk transcriptome data}

Gene expression was obtained with Illumina whole-genome Expression BeadChips (HT12v3) 
medRxiv preprint doi: https://doi.org/10.1101/2020.04.19.20071357; this version posted April 24, 2020. The copyright holder for this preprint (which was not certified by peer review) is the author/funder, who has granted medRxiv a license to display the preprint in perpetuity.

It is made available under a CC-BY-NC-ND 4.0 International license .

from peripheral blood RNA. Low quality samples were excluded. All probes with primer polymorphisms were left out, leaving 34,282 probes. The expression dataset is publicly available at GEO (Gene Expression Omnibus) under the accession number GSE48348. ${ }^{18}$ In this dataset, a total of 11 individuals with LOY were identified. In order to consider the effect of aging on LOY detection and to have the maximum power (i.e 3 controls per case), 32 age-paired normal samples per case were selected for the transcriptomic analyses.

The effect of SARS-CoV-2 infection on gene expression was assessed in independent biological triplicates of two different cell lines that were mock treated or infected with SARSCoV-2 (USA-WA1/2020). One corresponds to primary human lung epithelium (NHBE) and the other to transformed lung alveolar cells (A549). These data are available at GEO under the accession number GSE147507.

\section{Statistical data analyses}

Mosaic LOY detection and quantification was performed using MADloy tool which implements accurate LOY calling of SNP intensity data using the mean log-R ratio ( $\mathrm{mLRR}-\mathrm{Y}$ ) and Bdeviation derived-measures from chromosome $Y$ across subjects (http://www.github.com/isglobal-brge/MADloy). ${ }^{19}$ For each sample, MADloy first estimates the normalized $\mathrm{mLRR}-Y$ given by its ratio with the trimmed-mean of $\mathrm{mLRR}-Y$ values in the autosomes to discard regions with copy number alterations. B-deviation is calculated for the pseudoautosomal regions 1 and 2 (PAR1, 0-2.5Mb on both Xp and Yp; PAR2, 300kb on distal $X q$ and $Y q, M b 155$ and 59 respectively), and the $X Y$ transposed region (88-92Mb on $X, 2.5-$ $6.5 \mathrm{Mb}$ on $\mathrm{Y}$ ). The method is calibrated to detect mosaicism when the proportion of affected cells is above $15 \%$.

Gene expression data was quantile-normalized to the median. We analyzed linear regression residuals of gene expression data on fourty multidimensional scaling components, to correct for possible unwanted variability. Array quality was assessed using arrayQualityMetrics Bioconductor package. genefilter Bioconductor package was used to filter for features without annotation and/or exhibiting little variation and low signal across samples, leaving a total of 15,592 probes from 34,282. Differential expression (DE) between individuals with and without LOY was then performed using limma Bioconductor package. Significant DE genes were considered at false discovery rate $(F D R)<0.05$. Significant $D E$ genes at $p<0.001$ level were selected for Gene Ontology (GO) and KEGG (Kyoto Encyclopedia of Genes and Genomes) enrichment analysis with clusterProfiler Bioconductor package. Over-representation of DE genes in the gene set obtained from the analysis of SARS-CoV-2 infected cell lines $(p<0.001$ and log-foldchange $>0.5$ ) was performed using exact Fisher test. Cell-type composition of the 43 individuals with bulk transcriptomic data (11 LOY, 32 normal) was estimated using the 'xcell' method implemented in the immunodeconv R package. ${ }^{20}$ 
medRxiv preprint doi: https://doi.org/10.1101/2020.04.19.20071357; this version posted April 24, 2020. The copyright holder for this preprint (which was not certified by peer review) is the author/funder, who has granted medRxiv a license to display the preprint in perpetuity.

It is made available under a CC-BY-NC-ND 4.0 International license .

Association analysis between LOY status and clinical data, including blood cell counts and biochemical parameters, was assessed using linear models adjusted by age. All statistical analyses were performed using the statistical software $R$ version 3.6 .3 (http://www.rproject.org).

\section{Results}

Higher Covid-19 severity and mortality in males, a sex-bias that increases with aging

Accumulated data on the age-stratified case fatality ratio and infection fatality ratio in a large sample from two seriously affected countries, Italy and Spain, show a similar pattern with a remarkable sex-bias increase with advancing age (Figure 1A). Available reports are mostly based on hospital records and the same tendency has been reported in other countries. The numbers and proportions are likely to increase when individuals in aged care facilities are fully registered (Figure S1). COVID-19 lethality in Italy and Spain and LOY prevalence in men, as reported in the UK biobank, ${ }^{15}$ appear to increase exponentially with age (Figure 1B). Sex-biased COVID-19 mortality, while heterogeneous across countries, is consistently higher for men (Figure 1C).

\section{LOY detection and correlation with cellular and biochemical phenotypes}

We analyzed clinical parameters of 530 "apparently healthy" adult men from the Estonian Genome Center of the University of Tartu cohort (EGCUT) and classified them as having ( $n=28)$ or not having LOY $(n=502)$. Individuals with LOY have significantly age-adjusted decrease in red cell counts, decrease in mean corpuscular hemoglobin concentration and higher red cell distribution width, low basophil counts and borderline low lymphocyte proportions. Biochemical parameters revealed low albumin levels, low triglycerides and elevated homocysteine and urea levels (Table S1).

Blood transcriptome in individuals with LOY shows immune defects and cardiovascular risk

We also compared blood transcriptome from 11 men with LOY (median age: 69, range: 58-84) and 32 age-paired men without LOY (median age: 68, range: $60-87$ ) as controls. Multiple genes differentially expressed between groups were found, including autosomal and gonosomal genes (Tables S2-S4 and Figs S2-S3), providing insight into the mechanisms of disease susceptibility caused by LOY with implications for COVID-19. CSF2RA, located on the X-Y chromosome pseudoautosomal 1 (PAR1) region, is one of the most significantly down-regulated genes (Fig $2 A$ ), along with other multiple $Y$ chromosome genes with homologs on the $X$ chromosome that escape $\mathrm{X}$ inactivation and with known function in immunity (Table S4).

Top autosomal genes overexpressed in LOY, such as VWF and MYL9 (Fig 2A), are associated with cardiovascular risk. VWF codes for the von Willebrand factor (VWF), a pro-coagulant 
medRxiv preprint doi: https://doi.org/10.1101/2020.04.19.20071357; this version posted April 24, 2020. The copyright holder for this preprint (which was not certified by peer review) is the author/funder, who has granted medRxiv a license to display the preprint in perpetuity.

It is made available under a CC-BY-NC-ND 4.0 International license .

protein that promotes platelet adhesion and smooth muscle cell proliferation, with $M Y L 9$ encodes Myosin Light Chain 9, regulatory, important in inflammatory immune responses.

Since changes in gene expression may reflect differences in cell-type composition and functionality, we estimated the average cell-type functional composition of samples from individuals with LOY compared to those without LOY using bulk transcriptome data (Table S5). The results were consistent with LOY individuals having significantly decreased GM-progenitors and B cell naïve cells, along with increased counts of endothelial cells (Fig 2B). Enrichment gene set analysis using DE genes revealed a few categories significantly over-enriched, most notably the coagulation and cellular detoxification, the leukocyte migration and neutrophil activation (Fig 2C, Tables S6-S7). Overall, gene expression in LOY individuals leads to a downregulated immune score.

Down-regulated genes in LOY involved in response to SARS-CoV-2 infection

We tested whether the genes that participate in the primary response to SARS-CoV-2 infection were significantly deregulated in blood cells of individuals with LOY. We obtained 249 DE genes with SARS-CoV-2 infection in primary human lung epithelium (NHBE) and 130 for transformed lung alveolar (A549) (339 unique genes for the two cell lines). This gene set is highly overrepresented in several pathways including defense response to virus, IL-17, type I interferon and NF-Kappa B signaling (Table S8). From the DE genes in cells infected with SARS-CoV-2 13 were also de-regulated in individuals with LOY (Figure 3A and Table S9) indicating a strong significant over-representation ( $O R$ of enrichment $=7.23, p=1.5 \times 10^{-7}$ ). Most of these genes are interferon response genes (IFIT3, IFI44L, ITFT1, IFI6), which are down regulated in individuals with LOY (Figure 3B-D).

\section{Discussion}

Identification of the status of copy number for chromosomes $X$ and $Y$ in blood cells may have an immediate clinical relevance in the management of patients with COVID-19. Many of the biochemical and transcriptomic alterations found in individuals with LOY have been already associated to poor prognosis for SARS-CoV-2 infection. ${ }^{21-24}$

There is a number of genes located on the $Y$ chromosome with functional homologs on the $X$ chromosome that escape $X$ inactivation in females and have relevant functions in the immune system (Table S4). Cells with XCM are likely haploinsufficient for many of those genes, which are downregulated in individuals with mosaic XCM due to LOY. In particular, we observed low expression of CSF2RA in individuals with LOY, who also have low GM progenitors. CSF2RA codes for the alpha subunit of the heterodimeric receptor for colony stimulating factor 2 , a cytokine which controls the production, differentiation, and function of granulocytes and macrophages (GM-CSF) that are key for antigen presentation in infections, and is critical for $\mathrm{T}$ 
medRxiv preprint doi: https://doi.org/10.1101/2020.04.19.20071357; this version posted April 24, 2020. The copyright holder for this preprint (which was not certified by peer review) is the author/funder, who has granted medRxiv a license to display the preprint in perpetuity.

It is made available under a CC-BY-NC-ND 4.0 International license .

cell functions. GM-CSF also increases IL-2R and IL-2 signaling, which can increase expansion of lymphocytes and IFN- $\gamma$ production important for anti-viral response. Therefore, GM-CSF leads to enhanced protective responses. ${ }^{25}$ Loss or inactivation of both copies of the CSF2RA gene is associated with surfactant metabolism dysfunction-4 and pulmonary alveolar proteinosis, a primary immunodeficiency (OMIM 300700). ${ }^{26}$ As Leukine ${ }^{\circledR}$ (sargramostim, rhuGM-CSF) is currently being assessed in the SARPAC trial because of its potential positive effects on antiviral immunity and contribution to restore immune homeostasis in the lungs (https://clinicaltrials.gov/ct2/show/NCT04326920), our data suggest that patients with LOY might be predictive of a poor response due to their low expression of one of the receptor subunits for GM-CSF (CSF2RA).

Patients severely affected with COVID-19 have lower lymphocytes counts, specially T cells, higher leukocyte counts and neutrophil-lymphocyte-ratio, lower percentages of monocytes, eosinophils, and basophils, along with generally elevated levels of infection-related biomarkers and inflammatory cytokines, including IL-6. Helper, suppressor and regulatory T cells were all below normal levels in the severe group, with increased naïve helper $T$ cells and decreased memory helper $T$ cells ${ }^{1,24,27}$. We observed a significant overlap of deregulated genes in LOY individuals that participate in the immediate immune response elicited by SARS-CoV-2 virus infection. Some of these genes clearly activated in both studied cell types infected by SARSCoV-2 are markedly under expressed in individuals with LOY (SLPI, IFI6, IFIT1, IFIT3, and IFI44L) (Figure 3B-D). Secretory leukocyte protease inhibitor (SLPI) is a regulator of innate and adaptive immunity that protects the host from excessive inflammation in infectious disease, while the other four genes encode interferon induced proteins of the innate immune system that participate in the immediate host response to viral infections ${ }^{28}$. Dysfunctions of the adaptive immunity and interferon-mediated immediate host response in individuals with XCM/LOY are consistent with the observed sexual dimorphism in human immune system aging, and might underlie a poor immune response to SARS-CoV-2 infection. ${ }^{29}$ This patterns along with the increased severity in older males, suggests that XCM due to LOY may be one underlying factor for susceptibility to COVID-19 in a proportion of patients.

In addition to depleted hematopoietic progenitor cells and possible immunodeficiency, individuals with LOY may have increased levels of circulating endothelial cells, which are known biomarkers for endothelial dysfunction and cardiovascular disease. ${ }^{30}$ We observed upregulation of VWF and MYL9 in LOY. Pro-coagulant VWF promotes platelet adhesion and smooth muscle cell proliferation, and elevated levels of vWF have been associated with higher risk for thrombosis and cardiovascular disease. ${ }^{31}$ MYL9 is a ligand for CD69 to form a net-like structure inside blood vessels in inflamed lungs and is also a risk factor for cardiovascular disease risk found over-expressed in aged versus young injured arteries. ${ }^{32,33}$ As such, XCM/LOY could also contribute to COVID-19 lethality by its associated cardiovascular risk. 
medRxiv preprint doi: https://doi.org/10.1101/2020.04.19.20071357; this version posted April 24, 2020. The copyright holder for this preprint (which was not certified by peer review) is the author/funder, who has granted medRxiv a license to display the preprint in perpetuity.

It is made available under a CC-BY-NC-ND 4.0 International license .

In summary, XCM is relatively common in aging individuals with much higher frequency in males due to somatic LOY. It is associated to decreased progenitors and stem cells, along with immune system dysfunction and increased coagulation and cardiovascular risk as revealed by biochemical and gene expression data. Available data to date strongly suggest that this type of mosaicism may underlie at least part of the sex-biased severity and mortality of COVID-19 in aging patients, so additional studies are needed to validate and define the extent of our hypothesis. In order to achieve this goal and given its potential relevance for modulating prognosis and therapeutic response, we propose that evaluation of LOY and XCM by currently established methods as potential biomarkers should be implemented in both, retrospective studies and all prospective and currently ongoing clinical trials with different medications and vaccines for COVID-19. Testing for LOY/XCM at large scale among elderly people may also be helpful to identify still unexposed people who may be especially vulnerable to severe Covid-19 disease.

Author Contributions: Conceptualization, LAPJ and JRG; Funding acquisition, LAPJ, TE and JRG; Data provider, TE; Data analysis: JRG; Methodology, AC and JRG; Project administration, LAPJ and JRG; Software, JRG; Validation, AC and JRG; Supervision and visualization, LAPJ and JRG; Writing original draft, LAPJ and JRG; Writing review \& editing, LAPJ, AC and JRG. LAPJ and JRG contributed equally to this work. All authors have read and agreed to the published version of the manuscript.

Funding: The authors acknowledge support from the Catalan Department of Economy and Knowledge (SGR2017/1974, SGR2017/801) and the Spanish Ministry of Science "Programa de Excelencia María de Maeztu" (MDM-2014-0370) and "Centro de Excelencia Severo Ochoa" (CEX2018-000806-S), the Fondo Europeo de Desarrollo Regional, UE (RTI2018-100789-B-I00) and the Estonian Research Council (PUT1660). Authors also receive support from the Generalitat de Catalunya through the CERCA Program.

Acknowledgments: We thank Gemma Moncunill, Lluís Armengol and Jozef Gecz for their critical reading of initial versions of this manuscript.

Conflicts of Interest: LAPJ is founding partner and scientific advisor of qGenomics laboratories. The other authors declare no conflict of interest.

\section{REFERENCES}

1. Zhou, P., Yang, X. Lou, Wang, X.G., Hu, B., Zhang, L., Zhang, W., Si, H.R., Zhu, Y., Li, B., Huang, C.L., et al. (2020). A pneumonia outbreak associated with a new coronavirus of probable bat origin. Nature 579, 270-273.

2. Verity, R., Okell, L.C., Dorigatti, I., Winskill, P., Whittaker, C., Imai, N., Cuomo-

Dannenburg, G., Thompson, H., Walker, P.G.T., Fu, H., et al. (2020). Estimates of the severity 
of coronavirus disease 2019: a model-based analysis. Lancet Infect. Dis. Mar 30;S14733099(20)30243-7. doi: 10.1016/S1473-3099(20)30243-7. Online ahead of print.

3. Leong, H.-N., Earnest, A., Lim, H.-H., Chin, C.-F., Tan, C.S.H., Puhaindran, M.E., Tan, A.C.H., Chen, M.I.C., and Leo, Y.-S. (2006). SARS in Singapore--predictors of disease severity. Ann. Acad. Med. Singapore 35, 326-331.

4. Alghamdi, I.G., Hussain, I.I., Almalki, S.S., Alghamdi, M.S., Alghamdi, M.M., and ElSheemy, M.A. (2014). The pattern of Middle east respiratory syndrome coronavirus in Saudi Arabia: A descriptive epidemiological analysis of data from the Saudi Ministry of Health. Int. J. Gen. Med. 7, 417-423.

5. Channappanavar, R., Fett, C., Mack, M., Ten Eyck, P.P., Meyerholz, D.K., and Perlman, S. (2017). Sex-Based Differences in Susceptibility to Severe Acute Respiratory Syndrome Coronavirus Infection. J. Immunol. 198, 4046-4053.

6. Klein, S.L., and Flanagan, K.L. (2016). Sex differences in immune responses. Nat. Rev. Immunol. 16, 626-638.

7. Jin, J.-M., Bai, P., He, W., Liu, S., Wu, F., Liu, X.-F., Han, D.-M., and Yang, J.-K. (2020). Higher severity and mortality in male patients with COVID-19 independent of age and susceptibility. MedRxiv 2020.02.23.20026864.

8. Machiela, M.J., Zhou, W., Karlins, E., Sampson, J.N., Freedman, N.D., Yang, Q., Hicks, B., Dagnall, C., Hautman, C., Jacobs, K.B., et al. (2016). Female chromosome X mosaicism is agerelated and preferentially affects the inactivated $X$ chromosome. Nat. Commun. 7, 11843.

9. Fuchs, M.M., Attenhofer Jost, C., Babovic-Vuksanovic, D., Connolly, H.M., and Egbe, A. (2019). Long-Term Outcomes in Patients With Turner Syndrome: A 68-Year Follow-Up. J. Am. Heart Assoc. 8, e011501.

10. Wang, H., Zhu, H., Zhu, W., Xu, Y., Wang, N., Han, B., Song, H., Qiao, J. (2020)

Bioinformatic Analysis Identifies Potential Key Genes in the Pathogenesis of Turner Syndrome. Front Endocrinol. 11, 104.

11. Forsberg, L.A., Rasi, C., Malmqvist, N., Davies, H., Pasupulati, S., Pakalapati, G., Sandgren, J., Diaz de Ståhl, T., Zaghlool, A., Giedraitis, V., et al. (2014). Mosaic loss of chromosome $\mathrm{Y}$ in peripheral blood is associated with shorter survival and higher risk of cancer. Nat. Genet. 46, 624-628.

12. Zhou, W., Machiela, M.J., Freedman, N.D., Rothman, N., Malats, N., Dagnall, C., Caporaso, N., Teras, L.T., Gaudet, M.M., Gapstur, S.M., et al. (2016). Mosaic loss of chromosome $\mathrm{Y}$ is associated with common variation near TCL1A. Nat. Genet. 48, 563-568. 13. Loftfield, E., Zhou, W., Graubard, B.I., Yeager, M., Chanock, S.J., Freedman, N.D., and Machiela, M.J. (2018). Predictors of mosaic chromosome Y loss and associations with mortality in the UK Biobank. Sci. Rep. 8, 12316.

14. Thompson, D.J., Genovese, G., Halvardson, J., Ulirsch, J.C., Wright, D.J., Terao, C., Davidsson, O.B., Day, F.R., Sulem, P., Jiang, Y., et al. (2019). Genetic predisposition to mosaic $\mathrm{Y}$ chromosome loss in blood. Nature 575, 652-657.

15. Guo, X., Dai, X., Zhou, T., Wang, H., Ni, J., Xue, J., and Wang, X. (2020). Mosaic loss of human Y chromosome: what, how and why. Hum. Genet. 139, 421-446.

16. Cáceres, A., Jene, A., Esko, T., Pérez-Jurado, L.A., and González, J.R. (2020). Extreme down-regulation of chromosome $\mathrm{Y}$ and cancer risk in men. JNCI J. Natl. Cancer Inst. Jan 7:djz232. doi: 10.1093/jnci/djz232. Online ahead of print.

17. Caceres, A., Jene, A., Esko, T., Perez-Jurado, L.A., and Gonzalez, J.R. (2020). Extreme down-regulation of chromosome Y and Alzheimer's disease in men. Neurobiol. Aging. 90, 150.e1-150.e4.

18. tenOever, B.R., Blanco-Melo, D. (2020) Transcriptional response of human lung epithelial cells to SARS-CoV-2 infection. GSE147507. https://doi.org/10.1101/2020.03.24.004655. Mar 25 .

19. González, J.R., López-Sánchez, M., Cáceres, A., Puig, P., Esko, T., and Pérez-Jurado, L.A. (2019). A robust estimation of mosaic loss of chromosome Y from genotype-array-intensity data to improve disease risk associations and transcriptional effects. BioRxiv 764845. 20. Tsoucas, D., Dong, R., Chen, H., Zhu, Q., Guo, G., and Yuan, G.C. (2019). Accurate estimation of cell-type composition from gene expression data. Nat. Commun. 10, 1-9. 
medRxiv preprint doi: https://doi.org/10.1101/2020.04.19.20071357; this version posted April 24, 2020. The copyright holder for this preprint

(which was not certified by peer review) is the author/funder, who has granted medRxiv a license to display the preprint in perpetuity.

It is made available under a CC-BY-NC-ND 4.0 International license .

21. Wu, C., Chen, X., Cai, Y., Xia, J., Zhou, X., Xu, S., Huang, H., Zhang, L., Zhou, X., Du, C., et al. (2020). Risk Factors Associated with Acute Respiratory Distress Syndrome and Death in Patients with Coronavirus Disease 2019 Pneumonia in Wuhan, China. JAMA Intern. Med. Mar 13;e200994. doi: 10.1001/jamainternmed.2020.0994. Online ahead of print.

22. Tang, N., Li, D., Wang, X., and Sun, Z. (2020). Abnormal coagulation parameters are associated with poor prognosis in patients with novel coronavirus pneumonia. J. Thromb. Haemost. 18, 844-847.

23. Chen, G., Wu, D., Guo, W., et al. (2020) Clinical and immunologic features in severe and moderate Coronavirus Disease 2019. J Clin Invest. 1095:2020.02.16.20023903.

doi:10.1172/JCI137244

24. Zhou, F., Yu, T., Du, R., et al. (2020) Clinical course and risk factors for mortality of adult inpatients with COVID-19 in Wuhan, China: a retrospective cohort study. Lancet. 395, 10541062.

25. Autenshlyus, A., Arkhipov, S., Mikhailova, E., Marinkin, I., Arkhipova, V., and Varaksin, N. (2019). The Relationship Between Cytokine Production, CSF2RA, and IL1R2 Expression in Mammary Adenocarcinoma, Tumor Histopathological Parameters, and Lymph Node

Metastasis. Technol. Cancer Res. Treat. 18, 1533033819883626.

26. Suzuki, T., Sakagami, T., Rubin, B.K., Nogee, L.M., Wood, R.E., Zimmerman, S.L., Smolarek, T., Dishop, M.K., Wert, S.E., Whitsett, J.A., et al. (2008). Familial pulmonary alveolar proteinosis caused by mutations in CSF2RA. J. Exp. Med. 205, 2703-2710.

27. Wen, W., Su, W., Tang, H., Le, W., Zhang, X., Zheng, Y., Liu, X., Xie, L., Li, J., Ye, J., et al. (2020). Immune Cell Profiling of COVID-19 Patients in the Recovery Stage by Single-Cell Sequencing. MedRxiv 2020.03.23.20039362.

28. Majchrzak-Gorecka, M., Majewski, P., Grygier, B., Murzyn, K., and Cichy, J. (2016). Secretory leukocyte protease inhibitor (SLPI), a multifunctional protein in the host defense response. Cytokine Growth Factor Rev. 28, 79-93.

29. Márquez, E.J., Chung, C. han, Marches, R., Rossi, R.J., Nehar-Belaid, D., Eroglu, A., Mellert, D.J., Kuchel, G.A., Banchereau, J., and Ucar, D. (2020). Sexual-dimorphism in human immune system aging. Nat. Commun. 11, 751 .

30. Farinacci, M., Krahn, T., Dinh, W., Volk, H.-D., Düngen, H.-D., Wagner, J., Konen, T., and von Ahsen, O. (2019). Circulating endothelial cells as biomarker for cardiovascular diseases. Res. Pract. Thromb. Haemost. 3, 49-58.

31. Spiel, A.O., Gilbert, J.C., and Jilma, B. (2008). Von Willebrand Factor in Cardiovascular Disease. Circulation 117, 1449-1459.

32. Shehadeh, L.A., Webster, K.A., Hare, J.M., and Vazquez-Padron, R.I. (2011). Dynamic Regulation of Vascular Myosin Light Chain (MYL9) with Injury and Aging. PLoS One 6, e25855.

33. Kimura, M.Y., Koyama-Nasu, R., Yagi, R., Nakayama, T. (2019) A New Therapeutic Target: The CD69-My19 System in Immune Responses. Semin Immunopathol. 41, 349-358. 
medRxiv preprint doi: https://doi.org/10.1101/2020.04.19.20071357; this version posted April 24, 2020. The copyright holder for this preprint (which was not certified by peer review) is the author/funder, who has granted medRxiv a license to display the preprint in perpetuity.

\section{It is made available under a CC-BY-NC-ND 4.0 International license .}

\section{FIGURES}

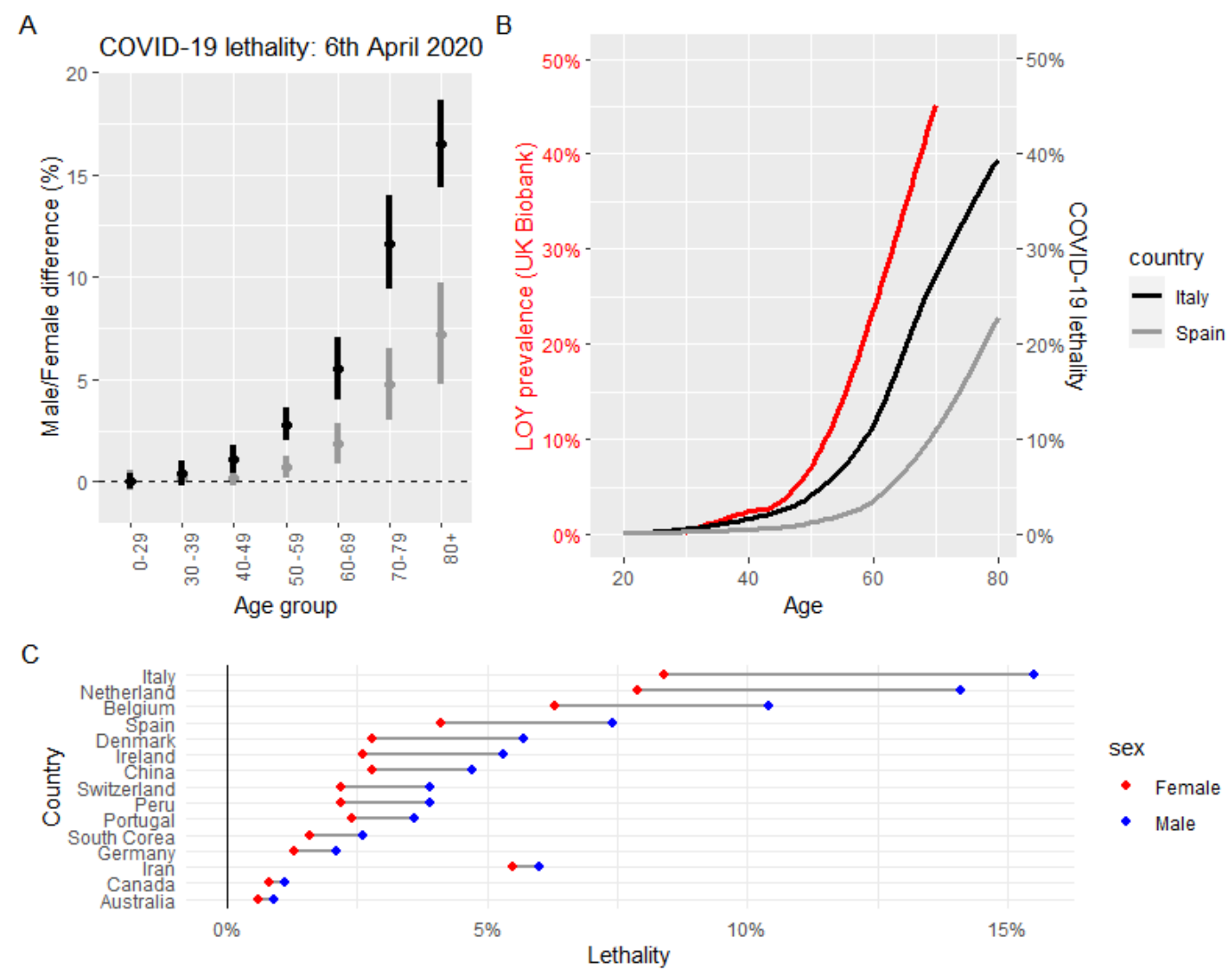

Fig1 (A) Increasing male to female difference in mortality rate (hospital deaths) for SARS-CoV-2 in Italy and Spain in the different age intervals (6 $6^{\text {th }}$ April, 2020). (B) Curves of mortality rate in Italy (black) and Spain (grey), as well as the prevalence of LOY in men by age (red $)^{4}$. (C) Consistent sex-bias in mortality in multiple countries despite non-uniform reporting. 
medRxiv preprint doi: https://doi.org/10.1101/2020.04.19.20071357; this version posted April 24, 2020. The copyright holder for this preprint (which was not certified by peer review) is the author/funder, who has granted medRxiv a license to display the preprint in perpetuity.

It is made available under a CC-BY-NC-ND 4.0 International license .

A
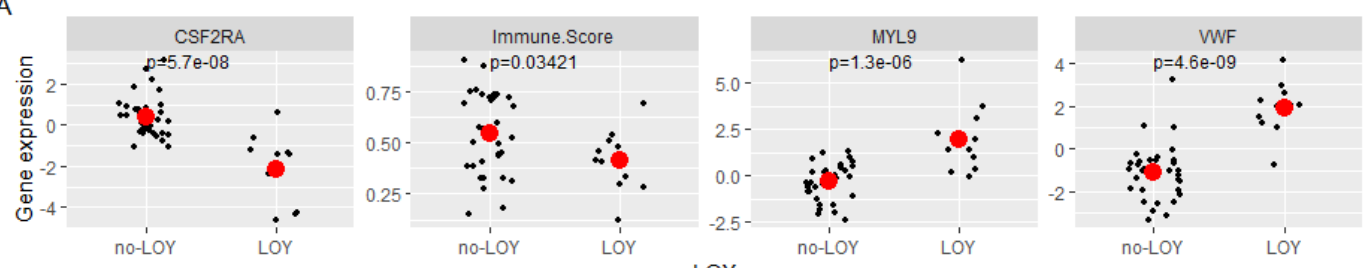

B
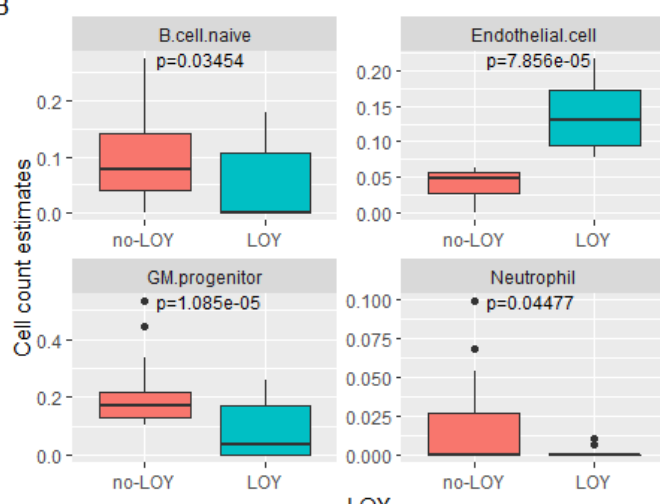

$\mathrm{C}$

LOY 官 no-LoY 由 LoY

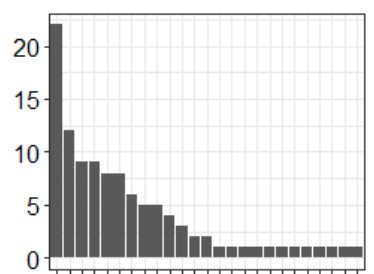

regulation of body fluid levels regulation of cell morphogenesis blood coagulation hemostasis coagulation

cell-substrate adhesion homeostasis of number of cells platelet degranulation myeloid cell homeostasis platelet activation

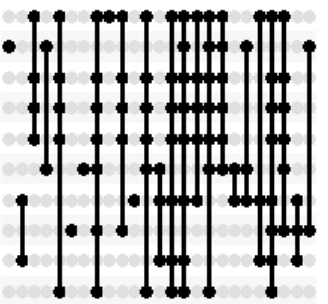

Figure 2: (A) Decreased expression of CSF2RA mRNA and an increased expression of $M Y L 9$ and $V W F$ in individuals with LOY compared with controls with no LOY (mean gene expression in red dot). (B) Different predicted cell counts underlying the transcriptomic differences between LOY cases and control individuals (normal). (C) Gene Ontology (GO) enrichment of top differentially expressed genes. 
medRxiv preprint doi: https://doi.org/10.1101/2020.04.19.20071357; this version posted April 24, 2020. The copyright holder for this preprint (which was not certified by peer review) is the author/funder, who has granted medRxiv a license to display the preprint in perpetuity.

It is made available under a CC-BY-NC-ND 4.0 International license .
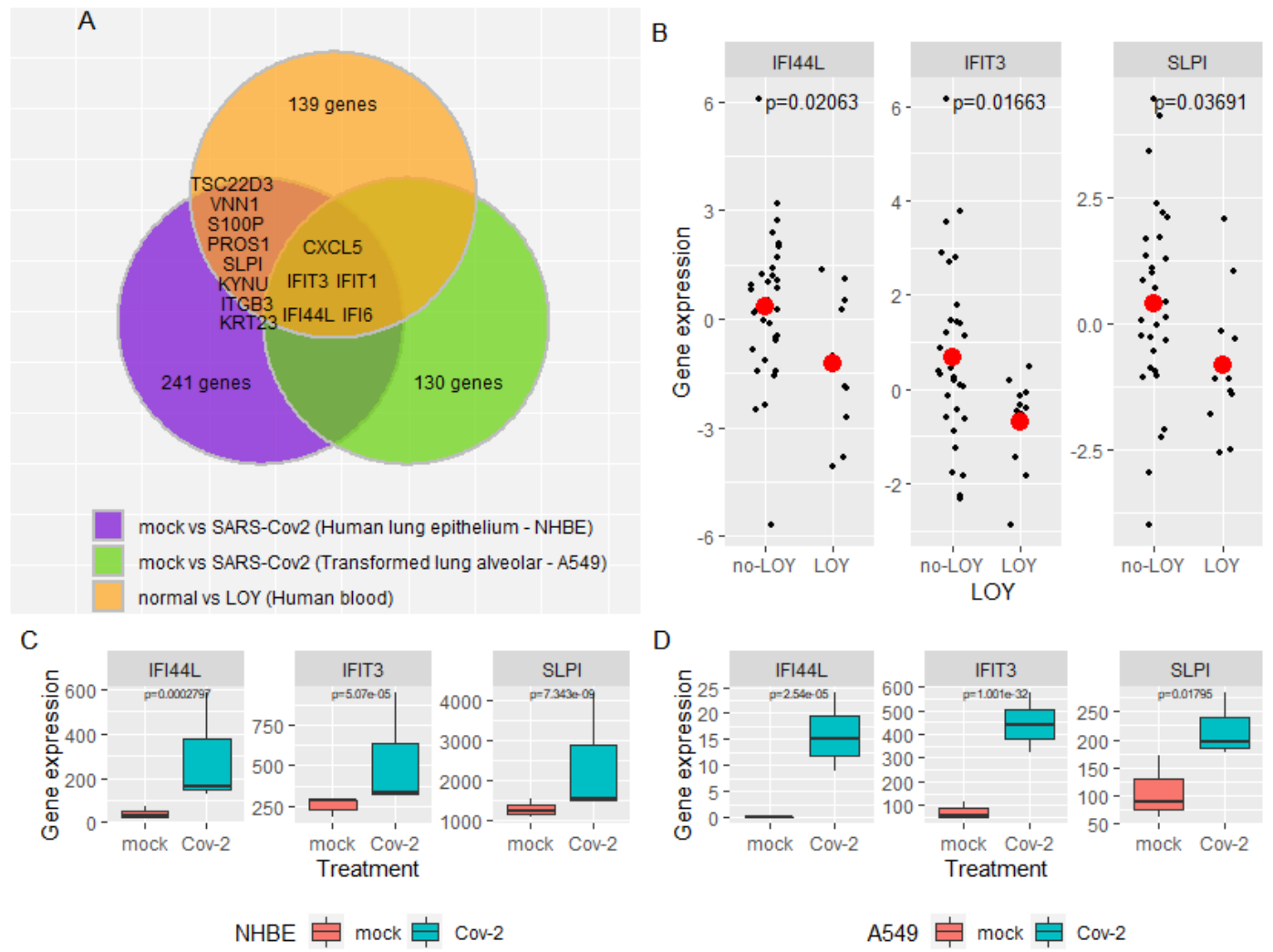

Fig 3: (A) overlap between top differentially expressed genes in individuals with LOY and deregulated genes in SARS-CoV-2 infected cells. Panels B, $\mathbf{C}$ and $\mathbf{D}$ show detailed gene expression patterns of some of these overlapping genes, down-regulated in individuals with LOY (B), and over-expression in NHBE (C) and A549 (D) cell lines infected with SARS-CoV-2. 